\title{
Financial Technology Phenomenon in Defense Economic Perspective
}

\author{
Supandi Halim, Muhammad Haikal Kautsar* \\ Indonesia Defense University \\ Bogor, Indonesia \\ *kautsarhaikal@yahoo.com
}

\begin{abstract}
Financial Technology become a enormous phenomenon in Indonesia Financial Industry. This Paper has purpose to study Financial Technology phenomenon in Defense Economic Perspective. This Study using qualitative approach to study the phenomenon. Data collected by study literature and short interview with interviewees. This result find that financial technology development in Indonesia bring both opportunity and threat to Indonesia Security in Defense Economic Perspective.
\end{abstract}

Keywords-financial technology, defense economic, digital finance, fintech

\section{INTRODUCTION}

Indonesia is one of many emerging market country in financial sector. The number of people, geograpic location, and natural resources makes Indonesia interesting as investment destination for investor. One of many sectors that intersting for investor is Financial Technology area. In 2018 the number investment in fintech reach US\$182.3 Million, raise up form US\$ 176,75 Million in 2018 [1]. Therefore the development of fintech industry in Indonesia is increase rapidly.

Besides the investment in fintech industry that encourage the development of fintech Industry there are several factor that also contribute to development of fintech industry, Table 1 show the factor that also influence in development of fintech industry.

TABLE I. THE FACTOR OF DEVELOPLEMENT FINTECH INDUSTRY

\begin{tabular}{|l|l|l|}
\hline \multicolumn{1}{|c|}{ Factor } & \multicolumn{1}{c|}{ Number } & \multicolumn{2}{c|}{ Information } \\
\hline Active Social Media & 130 Million People & $\begin{array}{l}70 \% \text { Mobile, 30\% } \\
\text { Mobile }\end{array}$ \\
\hline Internet Penetration & 143.2 Million & \\
\hline Population & 261.12 Million & \\
\hline Banked Populaiton & $48,9 \%$ & \\
\hline Mobile Subscription & 415.7 Million & \\
\hline
\end{tabular}

Sources:[2]

As shows by Table 1, the factor that also support the developlement of fintech industry. Hence, the digitalization in financial industry is inevitable. This phenomenon is interesting to be studied in perspective of Defense Economic. Because the appearance of financial technology could bring impact in positive way but also in negative way. Defense Economic will observe the positive impact and negative impact of fintech to national security and interest. Researchers expect this study will give benefit to regulator and scholar to in order of decission making and academic aspect.

\section{LITERATURE REVIEW}

This study use three theories to support and basic of study. First, theory of disruptive innovation, theory of fintech, and theory of Defense Economic.

\section{A. Disruptive Innovation Theory}

This theory propose that innovation could lead transformation in existing a system or market, with introduce praticality, ease of access, convenience, and efficiency in cost [3]. Disruptive innovations are inferior to incumbent products on accepted performance dimensions, but they offer a novel mix of attributes that appeals to fringe customer groups, notably those near the bottom of the market. Investmen in this innovation is unattractive for incumbents, but may be attractive to entrants who lack many (or any) customers and enjoy fewer competing investment opportunities. Consequently, incumbents are typically unmotivated to develop disruptive innovations that promise lower margins, target smaller markets, and introduce inferior products and services that their existing customers cannot use [4].

\section{B. Financial Technology}

"FINTECH" is an acronym which stand for financial technology, combining bank expertise with modern management science technique and the computer [5]. In simply way definition of fintech is combination between financial servies and technology implementation. Another scholar define fintech in broder way. Fintech is driven by technological advances, new service models have developed in the financial industry which offer additional opportunities to customers. Under the common denominator "fintech" these new business aim to challenge existing financial institutions by using technology to deliver value to the customer in an alternative way [6]. 
According to Indonesia Financial Authortity, in 2019 there is 18 type of fintech already operation in Indonesia. Table 2 show the type of fintech and short explanation of it is.

TABLE II. THE TYPE OF FINTECH AND SHORT EXPLANATION OF IT IS

\begin{tabular}{|l|l|}
\hline \multicolumn{1}{|c|}{ Type } & \multicolumn{1}{c}{ Short Explanation } \\
\hline P2P Lending & $\begin{array}{l}\text { Fintech platform that facilitate person with financial capability to meet person with requiring } \\
\text { financial support. }\end{array}$ \\
\hline Crowdfunding & Facilitate peoples to contribute in specific funding goals \\
\hline Payment & Facilitate payment with cashless system \\
\hline Financial Agent & Financial agent that use technology in services \\
\hline Credit Scoring & Help investor to calcute the risk of funding in investment \\
\hline Aggregator & Help consumer decide benefit and cost from every financial services available \\
\hline Project Financing & Facilitate to contribute in fundng specific project \\
\hline Social Network \& Robo Advisor & Help consumer to make financial decission with advice from robo \\
\hline Financial Planner & Financial consultant that use technology in services \\
\hline Blockchain Based & Used blockhain in financial services \\
\hline Online Distress Solution & Help consumer to find solution in financial problem \\
\hline Claim Service Handling & Help consumer to claim insurance \\
\hline E-KYC & Help investor to recongize the candidate of investmen receiver \\
\hline Verification Non-CDD & Use to verify the customer \\
\hline Tax and Accounting & Help customer in tax issue and bookkeeping \\
\hline Online Gold Depository & Online gold investment \\
\hline Digital Dire & Digital Investmen Real Estate \\
\hline Funding Agent & Funding Agent that use technology in services \\
\hline
\end{tabular}

The number kind of fintech is possibly to increase and develop, along with the development of technology.

\section{Defense Economic}

The Defense Economic is popularized by McGuire [8] in an essay "Defense Economics and International Security". In his essay, he defines Defense Economic as using Economic Approach in allocating resources, analysis of deterrence, model of alliance, national power, economic survival, and international trade, arm races and strategic interactions, economic ecology and international conflict in defense area of nations [8].

Furthermore develop the concept of defense economics especially in Indonesia case. According to his concept the Defense Economic also involve in matter of development of Military and Stratetegic Industry of a nation. Defense Ecomic has a role to make better managemetn in defense industry, creating independent defense industry to fulfil nation need of defence equipment and tools and reliable military product in international market [9]

\section{METHODS}

This study use qualitative approach to study the phenomenon of fintech. This research use primary and secondary data to be analyze, primary data in qualitative study is individual that involve and experienced the phenomenon [10]. Hence, they contain the object of research. We interview one of Indonesia Financial Authority about this topic. The secondary data of this study is compiled from literature and video.
Data analysis is effort of qualitative researcher to summarize the data that obtain accurately and reliable [11].

\section{RESULTS AND DISCUSSION}

In this chapter we will examine the result of our study and discuss the finding. We done a short interview with deputy commisioner of Indonesia Financial Authority. From the interview we found that there is a challenge that will be faced financial industry in the future. The type of fintech will be more variant, Meanwhile the literacy of society to fintech is required to be improved. If the development of fintech is not conformable with the literacy of people, there will be a escalation in financial crime in fintech industry.

The uplift of financial crime can lead to be a threat for national stability. In the Defense Economic perspective this is kind of nirmilitary threat for nation. Therefore it is required to have several mitigation and settlement step to encounter the threat. According to short interview with interviewees, there are three strategies to encounter the financial crime not to become a threat.

First, optimize task force. This task force has role to minimize the illegal fintech operation that can lead to financial crime. Second, increase the literacy program in society. The preventive way to make sure peoples avoid illegal fintech and get in trap of financial crime is incerase the literacy program. This program involve the regulator, industry, and academics to take a part in enchace financial literacy of society. Third, strengthen the regulation. The gap between regulation and development of technology creating space of unregulated operation. This is used by offender to commit financial crime in Fintech Industry. Therefore it is necessary to strengthe the regulation. 
This three strategies that we obtain from interviewees. We analyzed in defense economic theory. In Defense Economic theory there must be a synergy between law and economic, economic and law, and politic and economic [12]. The strategies to optimize task force of waspada investasi dan strengthen the regulation is a consistent with Defence Economic approach to create synergi between law and economic. The root of problem of financial crime is absence of law to protect consumer, hence offender use the gap to take advantage in the middle of absence of law.

The strategy to increase the literacy program in society is appropriate strategy in matter of Defense Economy. This strategy use political power to synergy with economy. Regulator (OJK) use his political power to encourage industry and academics to take a part and solemn in doing financial literacy program (economy). The regulator already use the political power wisely and precisely in matter of protecting national interest.

In addtion to negative side or challenge that sourced from development of fintech. There are also positive impact form fintech to Indonesia. According to short interview with interviewees, fintech contribute in postive way such as, 1) Increase Financial Inclusion. Fintech help peoples with unbanked accsess or banked to access financial servies more simple by using smartphone. Which is the number of people that Subscribe Mobile services is twice than number of Indonesia population, 2) Distribute Funding wider and easier. The presence of fintech faciliate SME and people in rural area to get funding. People and SME are unbankable can get fund by fintech company to be used in consumtive or productive activity.

In perspective of Defenes Economic, when people and SME can get funding easier it can support growth of economy by creating more consumtion and increasing investment. Furthermore it could lead to increase goverment spending especially in defense budget. Thus, when fintech is growing, expected that the allocation of defence budget (goverment spending) also could be increase.

\section{CONCLUSIONS}

Fintech Phenomenon in Defense Economics Theory bring both threat and opportunity to Indonesia Defense and Security. Therefore, it is required strategy to minimize the threat and optimeze the opportunity by government, industry, and academics.

\section{ACKNOWLEDGMENTS}

We grateful to Indonesia Defense University for support and facilitate and also we thankful to Indonesia Financial Authority (OJK) for cooperation.

\section{REFERENCES}

[1] D. Social, "Fintech Report 2018," Didapatkan dari https//dailysocial. id pada, vol. 11, 2018.

[2] F. Singapore, "Fintech Indonesia Report 2018-The State of Play for Fintech Indonesia," Accessed via http//fintechnews. sg/20712/indonesi a/fintech-indonesia-report-2018, 2018

[3] J.L. Bower and C.M. Christensen, "Disruptive technologies: catching the wave," 1995.

[4] C.M. Christensen, R. McDonald, E.J. Altman, and J.E. Palmer, "Disruptive innovation: An intellectual history and directions for future research,” J. Manag. Stud., vol. 55, no. 7, pp. 1043-1078, 2018.

[5] A. Bettinger, "Fintech: A series of 40 time shared models used at Manufacturers Hanover Trust Company," Interfaces (Providence)., pp. 62-63, 1972.

[6] E. Maier, "Supply and demand on crowdlending platforms: connecting small and medium-sized enterprise borrowers and consumer investors," J. Retail. Consum. Serv., vol. 33, pp. 143-153, 2016.

[7] Grup Inovasi Keuangan Digital OJK, "Tentang GESIT. Diambil kembali dari Electronic Financial Information Gate System (GESIT)." https://www.ojk.go.id/gesit.

[8] M.C. McGuire, "Defense economics and international security," Handb. Def. Econ., vol. 1, pp. 13-43, 1995.

[9] P. Yusgiantoro, Defense Economics: Theory and Practice. Jakarta: Gramedia Pustaka Utama, Jakarta, 2014

[10] J.W. Creswell, "Qualitative, quantitative, and mixed methods approaches." Thousand Oaks, CA: Sage, 2003.

[11] L.R. Gay, G.E. Mills, and P.W. Airasian, "Educational research: Competencies for analysis and application," 1992.

[12] Supandi, Introduction to Defence Economics. Bogor: Universitas Pertahanan Indonesia., 2019. 